\title{
Distribution, discharge and regional characteristics of springs in Poland
}

\author{
${ }^{1}$ Jagiellonian University, Institute of Geography and Spatial Management, 7 Gronostajowa Str., 30-387 Krakow, Poland. \\ ${ }^{2}$ University of Lodz, Department of Hydrology and Water Management, 31 Kopcinskiego Str., 31, 90-131 Lodz, Poland. \\ E-mail: P. Jokiel: joker@geo.uni.lodz.pl, P. Moniewski: moniek@geo.uni.lodz.pl \\ ${ }^{3}$ Maria Curie-Sklodowska University, Department of Hydrology, 19 Akademicka Str., 20-033 Lublin, Poland, \\ E-mail: zdzislaw.michalczyk@poczta.umcs.lublin.pl
}

A summary of the current body of knowledge on springs in Poland is presented. The paper relates the location of springs to geological structure, spring discharge, use of particular springs as well as threats associated with local groundwater nitrate pollution. Other key points include the uneven distribution of springs across Poland as well as varying levels of understanding of springs in northern Poland and in certain mountain ranges. The paper ends with a recommendation to monitor more springs over longer periods of time with respect to discharge and water quality.

\section{Introduction}

A spring is one of the forms of a natural outflow of groundwater at the surface of the Earth. It is a link connecting the underground and the surface parts of the water circulation system. To a geographer or a hydrologist, a spring outlet is the place where a river starts. Geologists and hydrogeologists perceive a spring as a kind of "unveiling" of groundwaters, a "key hole" that allows to have a peek into the underground system of water circulation and to gain the knowledge of the system and to prepare for its possible use.

In the world literature on spring hydrology most of the works cover karst springs. This is understandable since they are usually high discharge outflows. Thus, karst springs are used as a source of drinking water as well as for agriculture and power generation (Kresic and Stevanovic, 2010; Stevanovic and Eftimi, 2010). Most of the works are case studies. Monographs are rarely found in the literature on spring hydrogeology, especially those dealing with entire geographical regions or administrative units. Examples of such works are publications on springs in the United States: California (Waring, 1915), Virginia (Collins et al., 1930; McColloch, 1986), Pennsylvania (Flippo, 1974), Texas (Brune, 1975), Missouri (Vineyard \& Feder, 1982), Florida (Hartnett, 2000). Other examples would be publications on springs in Spain (Pérez, 1996), northern Portugal (Pacheco, Alencoão, 2002), and New Zealand (Scarsbrook et al., 2007). One of the volumes of Environmental Geology (vol. 27, 1996) contains several articles on springs in Great Britain, Egypt, Israel and Japan. A lot of information on regional issues in spring hydrology and utilization is to be found in a recent monograph by Kresic and Stevanovic (2010). There are many monographs on thermal springs in the USA, some covering springs in the entire country (Waring, 1965), and some in a specific state such as Wyoming (Breckenridge \& Hinckley, 1978), Utah (Mundorff, 1970) as well as Yellowstone National Park (Allen, 1936).

A summary of the current body of knowledge on springs in Poland is presented in this article. The depth of knowledge on springs in particular geographical regions of Poland is not the same. The research conducted in the lowland parts of the country was often limited in scope and focused on selected small parts of lake basins or river catchments. Most of publications resulting from such research deal with single entities representing a significant natural value or a tourist attraction. They are usually springs with high discharge rates.

The spatial distribution of springs and their characteristics in the southern, highland parts of the country are much better known. In the mountains the depth of knowledge on spatial distribution of springs is diverse, depending on the area. Unfortunately, there are not many springs, where discharge measurements were systematically performed for a long period of time. For that reason, most of data series resulting from measurements are not homogeneous. There are many springs, where only a single measurement of discharge was performed. It is rather not possible to collect and summarize fully comparable data sets representing the same spring characteristics of different regions of the country.

\section{Geographical and geological determinants of groundwater distribution in Poland}

Poland is mostly a lowland country. About $90 \%$ of the country, especially its central and northern parts, lies at elevations less than $300 \mathrm{~m}$ above sea level. The remaining territory are highlands that lie at elevations of 300-612 m, and mountains that usually lie at elevations of up to $1,200 \mathrm{~m}$, with the highest peak at 2,499 m. The division of Poland into hydrogeological regions is linked to the geographic division of Poland. The Hydrogeological Atlas of Poland (Paczynski, 1995) identifies three regions: lowland, highland, mountain. A newer and more detailed system of classification identifies 161 bodies of groundwater in Poland (Paczynski and Sadurski, 2007).

Lowland parts of Poland were shaped by a Pleistocene ice cap. Therefore, the surface of the land is rich in glacial features and 
sediments, primarily tills and sandy sediment formations that hold groundwater. These underground, mostly unconfined, water-bearing sandy layers hold considerable and sometimes very large quantities of water. The thickness of these layers increases northward. Elevation and depression of Cenozoic and Mesozoic structures can be found in their parent material.

The upland part of Poland is dominated by Mesozoic and Paleozoic elevation and depression structures with carbonate rocks, such as limestones, dolomites and marls that form large, mostly unconfined or only partly confined aquifers.

Mountainous parts of Poland consist of older geological formations. The Carpathians are an alpine-type orogeny. The mountains are primarily built of flysch formations (sandstones, shales, conglomerates) of a relatively low water bearing capacity. The Tatra Mountains are an exception. This is the highest part of the Carpathian Mountains. Its eastern part is primarily composed of granitoids of low water-bearing capacity. Its western part is mostly composed of water-bearing Mesozoic carbonate rock formations. They are partly covered with moraine sediments left by mountain glaciers.

An interesting although small range is the Pieniny massif, a short distance away from the Tatra Mountains. It is a part of the Pieniny Klippen Belt, which is a larger and very complex geological structure. Its composition is diverse, and so is its water bearing capacity, which is generally low. The Sudety Mountains are a Variscan (Hercynian) orogen, a mix of rocks of different ages and variable water-bearing capacities (Geological Map of Poland without Cenozoic deposits at the scale of 1:1 000000 on the website of the Polish Geological Institute: http://www.pgi.gov.pl/images/artykuly/ mapageol/mapa.jpg. A geological map with Cenozoic deposits at the scale of 1: 500000 is available at http://mapy-geol.pgi.gov.pl/mgp500/ MGP500_str1.html (Sept. 2011). A simplified geological map of Poland was published in Episodes, vol. 32, no. 3, p. 179).

Climate is the factor that in a natural way determines the schedule of recharging groundwater resources. Although the highest average monthly totals of precipitation in Poland occur in July, it is the spring thaws and the time right after the spring thaws that is the period, when groundwater is recharged the most (Chelmicki, 1993). It is also then, usually in April, that the water table of shallow groundwaters is at its highest level. The time when the level of the groundwater table is the lowest is the autumn (September-October), and in the mountains - the winter. In the high mountains (higher parts of the Carpathians and the Sudety Mountains), the highest groundwater table levels are delayed due to delayed spring thaws and occur concurrently with the period of increased summer rains.

\section{Discharge of springs and its variations}

One of the most important characteristics of every spring is its rate of discharge. The discharge of a spring varies over time. The variability may be diurnal, seasonal, or multi-annual. The quantity of water in a water-bearing layer or an aquifer may be estimated from the discharge, and its variability, of a spring that is recharged from the aquifer. Indirectly, this pertains also to the physical size of such groundwater reservoirs. Springs that are recharged by shallow groundwaters display a discharge pattern that coincides with the changes in the level of a groundwater table. This means that their discharge rates are highest in the spring, and lowest in the autumn. Karst springs behave in a similar way. Although they are usually recharged by deep groundwaters, it is the high hydraulic conductivity of the carbonate karstic rocks that causes a rather quick reaction of karst springs to the recharge conditions.

Given that most measurement data series are not homogeneous, especially valuable are the data series provided by the Institute of Meteorology and Water Management, which were obtained from its observation network that existed between 1965 and 1989. Table 1 shows discharge characteristics for five springs that are representative of the Mesozoic carbonate formations of the southern, highland part of Poland (Nos.: 47-48 \& 29, 64, 71 - Numbers correspond to the numbers in Fig.1), and one (21) that is representative of the Carpathian flysch sandstones. They are mostly fissure springs draining layers of a pressurized water table. The characteristics presented were calculated based on average monthly discharge values.

Considering an average discharge $\left(\mathrm{Q}_{\mathrm{s}}\right)$, the springs may be classified as 4th or 5th magnitude springs in Meinzer's units. Looking at Maillet's $(\mathrm{M})$ indicators of discharge irregularity and the variability indicators $\left(\mathrm{C}_{\mathrm{v}}\right)$, some of these springs may be classified as springs of little variability, some as springs of variable discharge, and some as springs of high discharge variability. The coefficients of autocorrelation $\left(\mathrm{R}_{1}\right)$ show that the discharge rates of these springs are characterized by significant inertia.

Spectral density functions of time series calculated by Jokiel (1994) indicate that the discharge rates of springs in Wawolnica, Slawkow and Wysokie $(79,29,64)$ are characterized by a very weak seasonal pattern of variability, with a tendency to form patterns that repeat in 2-year and 8-12-year long cycles. In the case of springs in Stroza, Bzow and Kromolow $(21,47,48)$, an annual discharge variability pattern is clearly noticeable, whereas patterns repeating in longer cycles are usually statistically insignificant.

Table 1. Hydrological regime of selected springs in Poland, based on data from the years 1965-1989 (Jokiel, 1994)

\begin{tabular}{|c|c|c|c|c|c|c|c|c|c|}
\hline Location & $\begin{array}{l}\text { Number } \\
\text { in Fig. } 1\end{array}$ & $\begin{array}{c}\text { Elevation } \\
\text { [m a.s.1.] }\end{array}$ & Aquifer & $\begin{array}{l}\text { Type of } \\
\text { spring }\end{array}$ & $\begin{array}{c}\mathrm{Qmax} / \mathrm{Qmin} \\
{[\mathrm{L} / \mathrm{s}]}\end{array}$ & M & $\begin{array}{c}\text { Qs } \\
{[\mathrm{L} / \mathrm{s}]}\end{array}$ & $\begin{array}{l}\mathrm{Cv} \\
{[\%]}\end{array}$ & $\mathrm{R}_{1}$ \\
\hline 1 & 2 & 3 & 4 & 5 & 6 & 7 & 8 & 9 & 10 \\
\hline Bzów & 47 & 405 & Jurassic limestones & Fissure & $8.7 / 0.04$ & 217 & 2.4 & 81 & 0.42 \\
\hline Kromolów & 48 & 382 & Jurassic limestones & Fissure & $28.4 / 0.11$ & 258 & 7.7 & 60 & 0.78 \\
\hline Stróza & 21 & 500 & Magura sandstones & Fissure/Layer & $1.5 / 0.1$ & 15 & 0.4 & 64 & 0.45 \\
\hline Wawolnica & 71 & 154 & Cretaceous siliceous chalk & Fissure & $236 / 50.5$ & 4.7 & 93.8 & 29 & 0.72 \\
\hline Slawków & 29 & 285 & Triassic limestones & Fissure & $162.5 / 7.1$ & 22.9 & 53.0 & 44 & 0.78 \\
\hline Wysokie & 64 & 228 & Cretaceous marlstones & Fissure & $278.2 / 2.3$ & 121 & 44.2 & 108 & 0.90 \\
\hline
\end{tabular}

$\mathrm{Q}_{\max } / \mathrm{Q}_{\min }$ - maximum/minimum discharge; $\mathrm{M}$ - Maillete's index; $\mathrm{Q}_{\mathrm{s}}$ - average discharge; $\mathrm{C}_{\mathrm{v}}$ - variability coefficient; $\mathrm{R}_{1}-$ coefficient of autocorrelation of monthly discharge rates. 


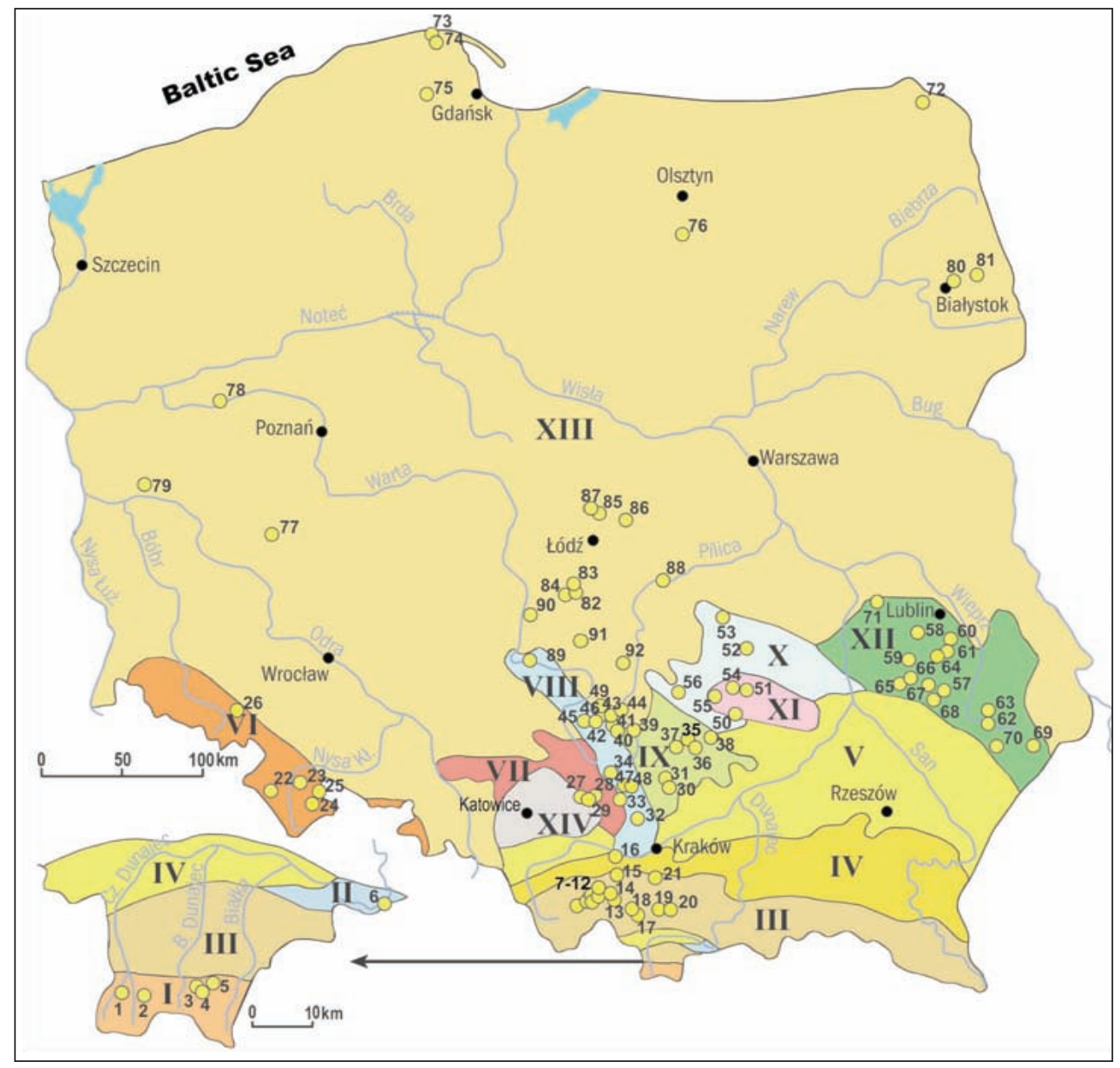

Figure 1. Spring types in Poland by region (according to Dynowska, 1986; modified).

Explanation: I. Tatra Mts.- numerous, high discharge ascending karst springs that issue from Mesozoic limestones and dolomites and little discharge fissure springs that issue from crystalline rocks; II. Pieniny Range - numerous fissure springs with little discharge rates, that issue from Mesozoic limestones, marlstones, and sandstones; III. Beskidy Range and Podhale Basin - very numerous fissure springs with little discharge rates, that are found in the Cretaceous and Tertiary flysch formations and springs that emerge from a porous weathered rock cover; IV. Carpathian Foothills less numerous fissure springs with little discharge rates, that are found in the Cretaceous and Tertiary flysch formations and springs that emerge from a porous weathered rock cover; V. Sub-Carpathian Basins - scarce springs with extremely low discharge rates emerging from porous formations of Tertiary sands and weathered rock cover; VI. Sudety Mts. - low discharge fissure springs that issue from crystalline rocks as well as from limestone, dolomite and sandstone of different age, and springs that emerge from a porous weathered rock cover; VII. Wyzyna Slasko-Krakowska highland - high discharge fissure springs, which are sometimes ascending springs, that occur in Triassic limestones and dolomites, and springs emerging from porous Pleistocene sandy formations; VIII. Wyzyna Krakowsko-Czestochowska highland - high discharge, karst and fissure springs, which are sometimes ascending springs, that occur in Jurassic limestones; IX. Wyzyna Malopolska highland - very high discharge, fissure springs and fissured layer springs, which are sometimes ascending springs, that issue from Cretaceous marlstones; X. Holy Cross Mts. - high discharge fissure springs and karst springs, sometimes ascending springs, that issue from limestones and sandstones; XI. Holy Cross Mts. -Paleozoic crystalline rock core - very low discharge springs seeping out of pores in weathered cover layers; XII. Wyzyna Lubelska and Roztocze highlands - very high discharge, fissure springs and fissured layer springs, sometimes ascending springs, that issue from Cretaceous marlstones and limestones; XIII. Polish Lowlands - scarce, mostly descending springs seeping out of pores in Pleistocene sands and gravel formations, locally springs supplied from underlying Mesozoic bedrock aquifers, with different discharge rates; XIV. Wyzyna Slaska highland - lack of springs due to economic development.

Selected springs or groups of springs are marked; their names and corresponding numbers are mentioned in the text.

\section{Regional differentia- tion of springs}

Until the 1950s the knowledge of spatial distribution of springs in Poland was rather superficial. The primary focus was on mineral water springs. Larger scale research on spring hydrology was undertaken in 1953 as part of the mapping process in order to produce a hydrographic map of Poland at the scale of 1:50000 (Klimaszewski, 1956). In the years that followed, more research on springs was conducted in many regions of Poland, mostly in the mountains and the highlands (Macioszczyk, 1959; Czarnecka 1964, 1970, 1973, 1975; Pawlik-Dobrowolski, 1965; Rederowa, 1965, 1971; Tlalka and Waksmundzki, 1968; Kleczkowski, 1971; Janiec 1972). In the 1980s and the 1990s the research efforts intensified; Drzal and Dynowska (1981), Dynowska (1983), Michalczyk (1986) and Jokiel (1994) added their contributions to the field of spring hydrology.

The first attempt to prepare a comprehensive work presenting the characteristics of springs in connection with the physiographic regions of Poland produced the publication by Dynowska (1986). Several years later, Dynowska (1994) published a map that illustrated the distribution and the diversity of springs in Poland (Fig. 1). Research that followed, conducted by various research groups allowed researchers to partially verify the contents of the already existing map, and new information was also added. The following part of this article is a systematic review of spring hydrology relationships in main regions of Poland.

The Carpathians are the area with the greatest number of springs in Poland. However, spring density index values are different in different parts of the large area (Pawlik-Dobrowolski, 1965; Kostrakiewicz, 1996). An obstacle to a credible evaluation of the spatial distribution of springs in particular parts of the Carpathians is the non-uniform knowledge of the terrain. The Tatra Mountains and the Pieniny Range in the Inner Carpathians 
are among the best known areas. The knowledge of springs in the Beskidy Range varies from place to place, and it is clearly worse in the eastern part of the Polish Carpathians, the Bieszczady Range.

Springs of the Polish Tatra Mountains have been mapped in detail since the 1960s (Wit and Ziemonska, 1960; Wit-Jozwik, 1974). In the granitoid parts of the Tatra Mountains the spring density index is low for springs originating in granitoid formations and it is about 1 spring per $\mathrm{km}^{2}$. It is significantly higher, about 9 springs per $\mathrm{km}^{2}$, in the case of springs flowing out of moraine formations and other surface deposits. In parts composed mostly of sedimentary rocks, primarily carbonate rocks, the index is about 5 springs per $\mathrm{km}^{2}$ (Malecka, 1997a).

Karst springs are the best known in terms of their spatial distribution and discharge characteristics. The springs: Chocholowskie (1), Lodowe (2),
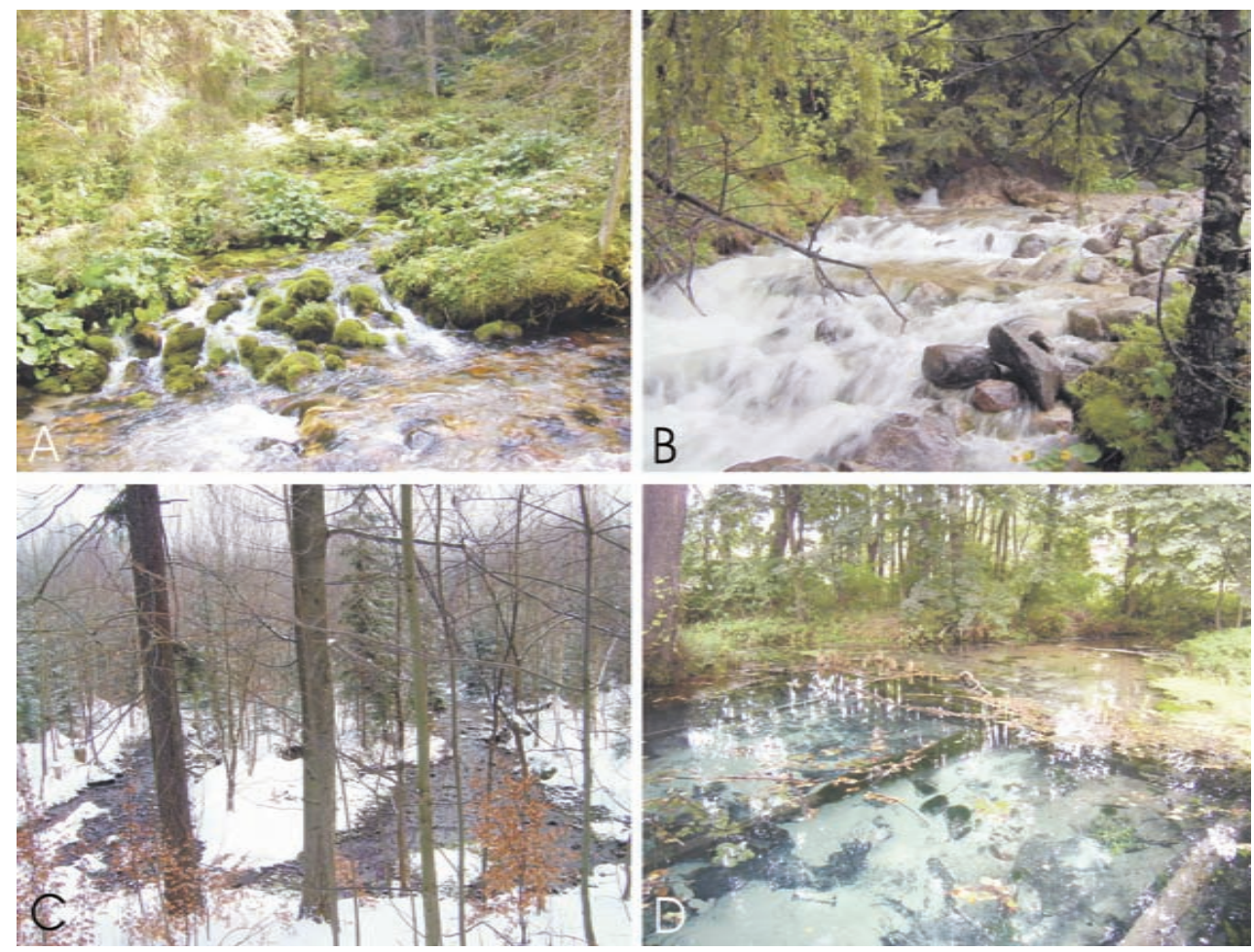

Figure 2. Lodowe (A) and Olczyskie (B) karst springs in the Tatra Mts., springs of the Bystrzyca Dusznicka River in the Sudety Mts. (C), and "Jordan" spring in Sciborzyce in the Wyzyna Malopolska highland (D)
Bystrej-Kalackie (3), Goryczkowe (4)

and Olczyskie (5) belong to the largest in the Tatra Mts (Figs. 2A and 2B). Systematic monitoring of changes in the discharge of springs, based on measurements of the water level in a stream that each spring produces, has been conducted in the Western Tatras since the beginning of the 1980s (Malecka, 1997a; Barczyk, 2008). An annual regime of discharge, is characterized by low values in the winter, followed by an increase that is due to spring thaws at the end of April and in early May. The peak water level and discharge values occur in May, and in some years in July, which is caused by an increased rainfall (Table 2). The spring water discharge regime may thus be described as snowmelt-rainfall related (primarily nival, but also pluvial), and in some cases as rainfall-snowmelt related (primarily pluvial, but also nival).

Research on the circulation of karst waters has been conducted since 1950s. At first, the coloring of water was used. Later on, chemical markers were used for water circulation research, and recently also biological markers and natural isotope markers were used (Zuber et al., 2008). The research allowed discovery of pathways of karst water circulation, to determine the exchange time for the water in aquifers recharging some springs, and to correct the estimates of the chemical denudation rate. The research also helped to determine a current reactivity of groundwater with respect to calcite (dissolution or precipitation), thus indicating the direction and rate of further development of karst systems (Gradzinski et al., 2009).

Significantly less is known of water circulation and spring discharge dynamics of the granitoid part of the Tatra Mountains. Most of the springs recharged by water from a system of fissures in the granitoid rocks are characterized by discharge values that are less than $0.1 \mathrm{~L} / \mathrm{s}$, and rarely reaching $0.5 \mathrm{~L} / \mathrm{s}$. Springs can also be found in areas situated on granitoide bedrock, but they flow out of moraine formations (secondary drainage). Sometimes they form arrays of springs.

Table 2. Largest karst springs of ascending type of outflow draining the sedimentary rocks of the upper nappe series of the Mesozoic age: limestones, dolomites, marls, sandstones (Malecka, 1997; Barczyk, 2008)

\begin{tabular}{|l|c|c|c|c|l|}
\hline $\begin{array}{c}\text { Name of the } \\
\text { spring }\end{array}$ & $\begin{array}{c}\text { Number } \\
\text { in } \\
\text { Fig.1 }\end{array}$ & $\begin{array}{c}\text { Elevation } \\
{[\mathrm{m} \text { a.s.1. }]}\end{array}$ & $\begin{array}{c}\text { Discharge } \\
\mathrm{max} / \mathrm{min} \\
{[\mathrm{L} / \mathrm{s}]}\end{array}$ & $\begin{array}{c}\text { Temp. } \\
{\left[{ }^{\circ} \mathrm{C}\right]}\end{array}$ & \multicolumn{1}{c|}{ Comment } \\
\hline Chocholowskie & 1 & 988 & $520 / 100$ & $5.0-6.3$ & $\begin{array}{l}\text { Partly supplied by water from ponors in the Chocholowskie stream } \\
\text { channel, and local cave systems (elev. 1019 m, dist. 1.3 km) }\end{array}$ \\
\hline Lodowe & 2 & 974 & $10000 / 80$ & $4.3-4.7$ & $\begin{array}{l}\text { Drains well-developed and deep cave systems in the Czerwone } \\
\text { Wierchy massif (elev. 2122 m, dist. 3.3 } \mathrm{km})\end{array}$ \\
\hline Bystrej-Kalackie & 3 & $1165-1170$ & $4110 / 65$ & $4.0-4.8$ & Drainage area is a matter of debate \\
\hline Goryczkowe & 4 & 1190 & $8650 / 121$ & $4.1-5.4$ & $\begin{array}{l}\text { Partly supplied by waters from ponors in the Stawów Gasienicowych } \\
\text { valley (elev. 1610 m, dist. 2.75 km) }\end{array}$ \\
\hline Olczyskie & 5 & 1070 & $7315 / 130$ & $4.2-4.4$ & $\begin{array}{l}\text { Connected with ponors in the Panszczyca valley (elev. 1430 m, } \\
\text { dist. 3.25 km) }\end{array}$ \\
\hline
\end{tabular}


Their discharge values are in the range from tenths to between 10 and $20 \mathrm{~L} / \mathrm{s}$. The low water-bearing capacity of a granitoid fissurebased aquifer and a shallow groundwater table in moraine formations favor the dependence on the conditions on the land surface, and therefore also a quick reaction of springs to recharge, which is reflected in their discharge. Maximum discharge occurs during the period of spring thaws, and the minimum discharge occurs in the winter months (Wit-Jozwik, 1974).

The Pieniny Range, similarly to the Tatra Mountains, is an area from which a good amount of knowledge has been gathered, including the knowledge of spring hydrogeology. A stationary network of water monitoring stations that was operated in Pieninski National Park in the first years of the $21^{\text {st }}$ century, allowed the evaluation of the discharge and dynamics of springs draining this exceptionally diverse and geologically complex area (Humnicki 2006, 2007). The discharge of most of the springs here is about $1 \mathrm{~L} / \mathrm{s}$. Springs with a greater discharge also occur, but they are rare. An example may be the "Hundred-Year-Old Spring" (6) located in the Slovakian part of the Pieniny Range. It was also determined that the recharge type of aquifers is nivo-pluvial, and that the flow rate and the reaction-torecharge type of particular springs differ significantly (Humnicki, 2006). In the case of springs located near dislocation zones, it was shown based on isotopic testing that the residence time of infiltration waters within rock formations was relatively long.

The Outer Carpathians (the Beskidy Range and the Carpathian Foothills) are characterized by the presence of numerous yet usually low discharge gravity springs, originating from flysch bedrock formations and weathered covers overlaying them. The aquifers are mostly porous and porous-fissure-type. The coefficient of filtration of the Paleogene and Cretaceous flysch bedrock varies from n. $10^{-6}$ to $n \cdot 10^{-3} \mathrm{~m} / \mathrm{s}$. The water-bearing capacity mainly depends on the fissure density, which is larger in thin-bedded bedrock formations than in massive formations (Chowaniec, 2009). Springs that flow out of geological formations dominated by massive sandstones are rare but have relatively large discharge values, ranging from several to less than $20 \mathrm{~L} / \mathrm{s}$; while in areas dominated by thin layers of sandstone and shale flysch, the spring density is larger, but the discharge values usually equal several tenths or hundredths of L/s.

An analysis of multi-annual data series of average monthly discharge values that included an autocorrelation analysis and the identification of model parameters for recession curves, have shown significant differences among properties of springs. They result primarily from the differences among water-bearing capacities of flysch aquifers that recharge the springs.

The springs of the Beskidy Range, listed in Table 3, are descending springs (flowing due to gravity) and sometimes mixed-type springs. They are flowing out through a fissure where a water-bearing layer intersects the ground surface. Sometimes they are fissure springs, with a difficult to determine share of infiltration water that gets through a weathered surface down to water-bearing rock formations. The water bearing layer consists of fissured sandstones and shales, locally marlstones of different flysch series and weathered bedrock (Table 3, col. 4). The spring outlets themselves are usually located on the slopes of valleys, rarely in valley floors. It should be emphasized that the water-bearing capacity of the Carpathian flysch depends almost entirely on the fissures within it. Water circulation conditions become more restricted with increasing depth or as the distance from tectonic fault zones grows. A typical characteristic of this part of the

Table 3. Hydrological regime of selected springs in the Western Beskidy Range, Carpathians (Jokiel, 1996, 1997)

\begin{tabular}{|c|c|c|c|c|c|c|c|c|c|c|c|}
\hline Location & $\begin{array}{l}\text { Number } \\
\text { in Fig. } 1\end{array}$ & $\begin{array}{c}\mathrm{H} \\
{[\mathrm{m} \text { a.s.l. }]}\end{array}$ & Aquifer & $\begin{array}{c}\mathrm{Q}_{\max } / \mathrm{Q}_{\min } \\
{[\mathrm{L} / \mathrm{s}]}\end{array}$ & M & $\begin{array}{c}\mathrm{Q}_{\mathrm{s}} \\
{[\mathrm{L} / \mathrm{s}]}\end{array}$ & $\begin{array}{c}\mathrm{V}_{\mathrm{s}} \\
{\left[\mathrm{m}^{3}\right]}\end{array}$ & $\begin{array}{c}\mathrm{C}_{\mathrm{v}} \\
{[\%]}\end{array}$ & $\mathrm{R}_{1}$ & $\mathrm{P}_{\max }$ & $\mathrm{P}_{\min }$ \\
\hline 1 & 2 & 3 & 4 & 5 & 6 & 7 & 8 & 9 & 10 & 11 & 12 \\
\hline Sól & 7 & 540 & $\begin{array}{l}\text { Magura shales and } \\
\text { sandstones }\end{array}$ & $3.0 / 0.03$ & 100 & 0.62 & 380 & 70 & 0.17 & III & $\mathrm{X}$ \\
\hline Rajcza & 8 & 495 & $\begin{array}{l}\text { Magura shales and } \\
\text { sandstones }\end{array}$ & $3.1 / 0.12$ & 26 & 0.33 & 2260 & 65 & 0.51 & VI & XI \\
\hline Wegierska Górka & 9 & 435 & $\begin{array}{l}\text { Sandstones, conglomerates } \\
\text { and shales }\end{array}$ & $4.6 / 0.02$ & 230 & 0.48 & 900 & 82 & 0.34 & III & XI \\
\hline Cisiec & 10 & 430 & $\begin{array}{l}\text { Krosnienskie sandstones } \\
\text { and shales }\end{array}$ & $1.0 / 0.02$ & 50 & 0.11 & 220 & 59 & 0.41 & III & $\mathrm{X}$ \\
\hline Swinna & 11 & 380 & $\begin{array}{l}\text { Podmagurskie sandstones } \\
\text { and shales }\end{array}$ & $1.4 / 0.23$ & 6 & 0.30 & 1150 & 18 & 0.40 & VI & $\mathrm{XI}$ \\
\hline Czernichów & 12 & 325 & $\begin{array}{l}\text { Godulskie sandstones } \\
\text { and shales }\end{array}$ & $15.0 / 0.03$ & 700 & 0.90 & 1900 & 131 & 0.71 & IV & $\mathrm{XI}$ \\
\hline Maków & 13 & 360 & Alluvial sands and gravels & $0.6 / 0.13$ & 5 & 0.21 & 3550 & 64 & 0.92 & VI & XII \\
\hline Sucha Beskidzka & 14 & 330 & Magura sandstones & $0.7 / 0.01$ & 70 & 0.08 & 250 & 74 & 0.55 & $\mathrm{~V}$ & $\mathrm{X}$ \\
\hline Babica & 15 & 290 & Wierzchowskie shales & - & - & 0.21 & - & 37 & 0.86 & VI & $\mathrm{X}$ \\
\hline Spytkowice & 16 & 598 & Lackie marls & $1.4 / 0.07$ & 20 & 0.35 & 780 & 59 & 0.44 & III & XI \\
\hline Jordanów & 17 & 450 & Magura sandstones & $1.4 / 0.46$ & 3 & 0.81 & 6800 & 25 & 0.69 & VI & $\mathrm{XI}$ \\
\hline Grzechynia & 18 & 572 & Magura sandstones & - & - & 0.83 & - & 98 & 0.39 & IV & XI \\
\hline Tenczyn & 19 & 440 & $\begin{array}{l}\text { Magura sandstones, shales } \\
\text { and marls }\end{array}$ & - & - & 0.17 & - & 8 & 0.85 & VI & II \\
\hline Mszana Górna & 20 & 490 & $\begin{array}{l}\text { Krosnienskie sandstones } \\
\text { and shales }\end{array}$ & $1.0 / 0.05$ & 20 & 0.28 & 980 & 39 & 0.52 & IV & $\mathrm{XI}$ \\
\hline Stróza I & 21 & 500 & Magura sandstones & $4.3 / 0.1$ & 86 & 0.06 & 1050 & 76 & 0.03 & III & $\mathrm{X}$ \\
\hline
\end{tabular}

$\mathrm{H}$ - spring elevation; $\mathrm{Q}_{\max } / \mathrm{Q}_{\min }$ - maximum/minimum discharge; $\mathrm{M}$ - Maillete's index; $\mathrm{Q}_{\mathrm{s}}$ - average discharge; $\mathrm{V}_{\mathrm{s}}$ - average water holding capacity; $\mathrm{C}_{\mathrm{v}}$ - variability coefficient; $\mathrm{R}_{1}$ - coefficient of autocorrelation of monthly discharge rates; $\mathrm{P}_{\max }, \mathrm{P}_{\min }-$ month of maximum and minimum discharge rate (I-XII - January-December) 
Carpathians is the presence of many small aquifers, frequently isolated from each other, that are water-bearing layers in which the waterbearing capacity depends on the fissures within the layer. That is why the discharge rates of the springs are low and it places them below the 5th magnitude per Meinzer's scale. These springs may be classified as springs of variable discharge, some as springs of high discharge variability, and some as springs of little variability - although these are rare. The classification of these springs may be confirmed by the Maillete's (M) index of discharge irregularity and the variability index $\left(C_{\mathrm{v}}\right)$ (Table 3, col. 5, 6, 9). The springs flow out of aquifers, but the water bearing capacities of the aquifers are usually small and do not exceed $10,000 \mathrm{~m}^{3}$ (Table 3 , col. 8). Thus they are 10-100 times smaller than the capacities of aquifers found in the fissured carbonate rocks or the capacities of porous, water-bearing layers found in the glacial sediments of central Poland.

Spring discharge inertia, measured by the first coefficient of autocorrelation (Table 3, col. 10), is different for different springs. However, in most cases, the significance of $R_{1}$ coefficients is at a level $a=0.05$. At the same time, the next coefficients of autocorrelation $\left(\mathrm{R}_{2}, \mathrm{R}_{3}\right.$ etc.) are not statistically significant. Thus the "hydrologic memory" of the aquifers, supplying water to springs that originate from them, is short and does not exceed one month. At the same time the size of the aquifers is small, the water reserves in them are small, and they dry up quickly - the water exchange rate in water-bearing layers is very high.

Spring discharge is usually greatest in the spring (March, April), which is the case for the 9 mentioned springs, or in the early summer (June) - for the other 6 springs. The minimum discharge values occur in the autumn (October, November) - 13 springs, and are rare in the winter - 2 springs (Table 3, col. 11, 12). Highly variable springs of low discharge inertia (small aquifers, holding small water reserves, of significant drainage) are characterized by maximum discharge values in the spring and minimum values in the autumn. Springs of moderate variability and elevated discharge inertia (aquifers of significant size, of relatively high water reserves) are characterized by greatest flows in the summer and the smallest in the winter.

THE SUDETY MOUNTAINS are a very diverse area when it comes to the distribution and types of springs. This is a result of their complex geological structure. In the Western Sudety massifs, composed of crystalline and metamorphic rocks, most groundwater outflows are located on hill slopes; they are: very low discharge hillside springs (45\%) and bog-springs (35\%), flowing out of the cover layers of rubble and weathered rocks. Fissure springs comprise about $20 \%$ of all springs here (Tomaszewski, 1974). In the catchments of the Snieznik massif, composed of gneisses and shales, most springs are hill slope springs (65\%). Typical for the region is the presence of seepage springs, however the percentage of "typical" tubular or fracture springs is higher and is $76 \%$. Descending springs, fissured layer springs or fissure contact springs, are the most common types of springs flowing out of Cretaceous sandstones of the Intra-Sudety Basin (Gory Stolowe Range). Small karst fissure springs and stone rubble springs are also present in some places.

The greatest density of springs per unit area is found in the upper parts of catchments of the streams draining the highest parts of the Sudety Mountains (7-10 springs per $\mathrm{km}^{2}$ ). Larger groups of springs are often associated with tectonic fault lines, and also with interlayers of fractured or karstified limestones and dolomites. The spring density index for the catchments of certain streams may reach 60 springs per $\mathrm{km}^{2}$.
The discharge of springs found in the Sudety Mountains is generally low. This is due to the significant lithological diversity of rocks in the area and their usually low water transmissivity. The discharge in $70 \%$ of the springs in the Gory Stolowe Range is smaller than $0.6 \mathrm{~L} / \mathrm{s}$. Only in $4 \%$ of cases it exceeds $6 \mathrm{~L} / \mathrm{s}$. In the Kamienna River catchment the discharge values of most springs is in the range of $0.1-1 \mathrm{~L} / \mathrm{s}(65 \%)$. The discharge of only several springs reaches 3.7-9.0 L/s. Somewhat greater discharge values are typical for karst fissure springs, for example in the case of the vauclusian (rising) spring in the Klesnica Valley (24) - periodically even up to $100 \mathrm{~L} / \mathrm{s}$. Rather significant discharge rates are also typical for springs in tectonic fault zones.

The springs of the Bystrzyca Dusznicka River (22) are large permanent springs in the Sudety Mountains - their discharge values reach $60 \mathrm{~L} / \mathrm{s}$ (Fig. 2C). Other springs are a karst spring called "Romanowskie Zrodlo" (23) in the Pasmo Krowiarek Range with a discharge of about $25 \mathrm{~L} / \mathrm{s}$, and karst vauclusian springs in the valleys of Przylecznica and Jastrowiec (26) in the Gory Kaczawskie Mountains (12-30 L/s). The mineral springs in Kudowa, Duszniki and Polanica, where water intakes exist so that the acidulous springs may be used, as well as the sulfurous water springs in Ladek Zdroj (25) are also examples of well-known springs. So far, little is known about groundwater nitrate contamination in the area.

THE POLISH HIGHLANDS are areas, of which the knowledge of springs is best in the entire country. This is true of both the quantitative characteristics (spring density per unit of area, spring discharge, water resources, etc.) as well as the qualitative characteristics of springs (water cleanliness and the ecological state, natural landscape attractions, etc.). There are numerous springs in highland areas. Their discharge values are among the greatest in Poland, outside of the Tatra Mountains, and they reach $300 \mathrm{~L} / \mathrm{s}$. The springs flow out of many different kinds of water-bearing formations (porous, fissured, and karstic fissured). Among the springs are descending springs as well as ascending springs. Also the age of water bearing formations differs from one formation to another: from fissured Devonian rocks, through carbonate sediments of Paleozoic and Mesozoic and compact Tertiary series, up to unconsolidated cover layers of weathered rock and Quaternary sands.

The Highlands: Wyzyna Slasko-Krakowska and Wyzyna Malopolska, as far as the spring phenomena are concerned, belong to a group of areas, just like the Tatra Mountains, the Pieniny Range, the Wyzyna Lubelska and Roztocze highlands, that are the most interesting in Poland. High discharge karst springs, karst layer springs and fissured layer springs flow out of high capacity aquifers composed of dolomites, limestones and Mesozoic marlstones, and of Tertiary sediments. The discharge rates of some of the springs reach values exceeding $100 \mathrm{~L} / \mathrm{s}$. Research on the springs in this area was begun by Czarnecka (1973, 1975). Dynowska (1983) prepared detailed descriptions, based on research in the field, of 246 springs of the area between Krakow and Wielun. The same kind of research of the same springs was repeated 30 years later by Chelmicki (2001). This allowed to evaluate the magnitude of changes that took place in the meantime. Other research concentrated on recognizing the natural and anthropogenic conditions of spring water quality and spring dynamics (Rozkowski 1998, 2006; Siwek, 2004; Absalon, 2007).

The spring density in an area composed of massive and laminated 
Upper Jurassic limestones is low (about 0.2 spring per $\mathrm{km}^{2}$ ) while the discharge values may be very different, which indicates an internally diversified system (transmissivity coefficient: $0.1-280 \mathrm{~m}^{3} /$ h; Sadurski, Paczynski, 2007). Spring discharge values are usually small - generally several L/s, more rarely $10-90 \mathrm{~L} / \mathrm{s}$, and sporadically above $100 \mathrm{~L} / \mathrm{s}$ (Czarnecka, 1975). It has been found that a spring response time to the pressure resulting from a recharge due to inflow of snowmelt water (initial and maximum response) equals 5-60 and 17-79 days, respectively. The response time of springs to a recharge from rainfall is even more variable. It is likely that it results from the fact that rainfall amounts over certain area are more variable than the amounts of water from a uniformly melting snow cover. Research based on isotopic testing of groundwaters, including spring waters, has shown that the residence time of water in local fissured karst systems was shorter than 6 years. However, in the case of flow-through waters within watershed boundary zones, in porous-fissured karst systems that period may exceed even 100 years (Rozkowski, 2006).

The Wyzyna Miechowska highland is a relatively small region composed of Upper Cretaceous marlstones (transmissivity coefficient: $102-980 \mathrm{~m}^{2} / \mathrm{h}$; Sadurski, Paczynski, 2007). It is located to the east of the Wyzyna Krakowsko-Czestochowska highland. The spring density there is even smaller ( 0.07 spring per $\left.\mathrm{km}^{2}\right)$, but discharge values of particular springs are high, quite often they exceed $100 \mathrm{~L} / \mathrm{s}$.

The area described is in the proximity of large industrial centers, and it is exposed to industrial pollution. It is ecologically endangered, particularly by zinc and lead ore extraction in the Olkusz area and coal mining in the Upper Silesian region, as well as by the lowering of the water table related to extraction. Since a large part of the area is used for agriculture, yet another problem arises, which is the pollution of groundwater in unconfined aquifers with nitrogen compounds, primarily nitrates with average values in the Jurassic aquifer of $17 \mathrm{mg} / \mathrm{L}$, and maxima reaching $49 \mathrm{mg} / \mathrm{L}$ (Zurek et al, 2010).

One of the research results, initiated by Dynowska (1983), was the identification of especially valuable springs. Some of the springs were later designated as natural monument protection areas, due to their unique scientific, educational and cultural values as well as for being natural landscape attractions. A map of protected springs, declared as monuments of nature in Poland (Bascik et al., 2009), shows that in the area described here there is the greatest concentration of such springs outside of the Wyzyna Lubelska and Roztocze highlands.

The following springs are some of many examples: a group of springs in Strzemieszyce near the city of Dabrowa Gornicza (27), the springs of the Centuria River in the catchment of the Chechlo River (28), the springs in the catchment of the Dlubnia River located in Sciborzyce (30; Fig. 2D) and in Imbramowice (31), the spring in Jerzmanowice in the catchment of the Rudawa River (32), the seepage springs areas in Zurada (33) and in Cieslin (34) - in the catchment of the Przemsza River. Other examples include the springs in the Szreniawa River catchment: in Biskupice (35), in Kamienczyce (36) and in Golcza (37), and also the springs in the Nidzica catchment in Maciejow (38). The following are noteworthy springs in the Pilica River catchment: the seepage springs area in Lany Wielkie (39) and in Siamoszyce (40), the spring in Zdow (41), the springs in Skolniki (42), Lelow (43), and Biala Wielka (44). There are also valuable springs in the Warta River catchment, in Zaborze (45), Zloty Potok (46), and Julianka (49). These springs have high discharge values, several tens of L/s. Some of the springs are characterized by a unique and natural beauty. Many of the springs were classified as monuments of nature and they are on a list of protected natural areas.

In the gypsum formations of the Niecka Nidzianska basin there are also numerous springs. Most of them are vauclusian (ascending) springs with discharge rates of up to several tens of L/s. A significant number of springs were also found in the upper part of the Wschodnia River catchment. The spring density index in the catchments of the Koprzywianka and the Opatowka Rivers is rather small, and discharge rates of the springs located there are usually not in excess of $5 \mathrm{~L} / \mathrm{s}$ (Suligowski et al., 2009).

Many groundwater outlets are mineral springs containing chloride, sodium and sulfide ions. Some of the springs are used for health resort-type treatments at well-known health spa centers in Busko and Solec Zdroj. Natural mineral water springs occurred also in other towns in the region, but the groundwater resources were depleted by the health spa centers, and those springs disappeared or their discharge substantially diminished (Lajczak, 2001).

The Holy Cross Mountains (Gory Swietokrzyskie) are a region of very diversified hydrologic characteristics of springs. This is due to the fact that the geological structure of particular areas within the region is mosaic-like. The spring density index calculated for the whole region of the Holy Cross Mountains is less than 1 spring per $\mathrm{km}^{2}$ (Czarnecka, 1973). Spring outlets are most numerous within the area of the crystalline rock core of the mountains. A distribution of spring locations is clearly related to the ways the tectonic dislocations and faults run through the area. The spring density index within the area of Cambrian rock formation is highest here and it equals 1.9 spring per $\mathrm{km}^{2}$. Small fissure springs and springs located on tectonic faults are most common types of groundwater outlets here. They may be perennial or periodic springs with discharge rates in the range of 0.1-0.5 L/s. Springs flowing out of talus have similar discharge rates, with an average of $0.2 \mathrm{~L} / \mathrm{s}$.

Hill slope springs, and layer springs associated with tectonic faults, flowing out of Early Jurassic sandstones have discharge rates of 0.3$1.0 \mathrm{~L} / \mathrm{s}$. However, discharge rates of fissure and karst springs flowing out of Devonian formations are greater and reach 1-10 L/s. A special example may be the springs in Bialogon (50) - their discharge rates reach $80 \mathrm{~L} / \mathrm{s}$. Also the Triassic formations are a high water-bearing capacity aquifer for large springs with discharge rates of up to $20 \mathrm{~L} / \mathrm{s}$. For example, the Lubrzanka River originates from springs flowing out of such formations (30). Some of the bigger springs are the "Bialy Stok" ("White Slope") Spring (52) in the headwater area of the Kamienna River (16 L/s), the "Kaski Stok" Spring (53) in the upper Radomka River catchment (7.3-19.8 L/s), and the springs of the upper Bobrza River with discharge rates ranging from 0.5 to $8.1 \mathrm{~L} / \mathrm{s}(54)$. Springs are not as numerous in the Pilica River catchment, where the Mesozoic rocks contact the Pleistocene glacifluvial formations. An example may be the spring in Borki (55) in the catchment of the Czarna Taraska River with a discharge equal to $4.5 \mathrm{~L} / \mathrm{s}$ and a vauclusian spring in Skalka Polska (56) with a discharge equal $23.5 \mathrm{~L} / \mathrm{s}$

The Wyzyna Lubelska and Roztocze highlands are known for their numerous springs with high discharge rates. Water circulation in an active zone of water exchange occurs in the carbonate rocks of the Upper Cretaceous origin formed as siliceous chalk, gaize, marlstone and chalk. In the northwestern part of the region the water bearing layers are also composed of Paleocene gaizes and marly 
limestones, whereas in the southern part the water-bearing layers are composed of Neogene limestones and sandstones. Spring hydrology research and measurements in the Lublin region are a tradition that is over 100 years old. The first pieces of information that were published were about ferruginous springs and springs in the vicinity of the city of Lublin. Since the beginning of the 1950s, periodic measurements of discharge rates for selected springs have been performed in the Lublin region (Michalczyk, 1986). Information has been gathered on some 1,600 springs present in the region of an area of about 12,200 $\mathrm{km}^{2}$. The spring outlets are found at elevations from 122 to $335 \mathrm{~m}$ above sea level.

The presence of springs is strongly related to the tectonic structure and lithology of water-bearing layers. Most spring outlets are located in river valleys $(87 \%)$. Only a few $(11 \%)$ can be found on valley slopes at higher elevations, almost on highland plateau crests. The average spring density index for the region is 0.12 spring per $\mathrm{km}^{2}$. The greatest density of perennial springs has been found in the western part of the Wyzyna Lubelska ( 0.14 spring per $\left.\mathrm{km}^{2}\right)$ and in the Roztocze (0.13 spring per $\mathrm{km}^{2}$ ) highlands (Michalczyk, 2001).

In this region 59\% of known springs flow out of Upper Cretaceous siliceous chalk and marlstone. Only $6 \%$ of springs are recharged by waters circulating in Miocene or Paleocene limestones that are found in the zones of the northern or the southern edge of the Wyzyna Lubelska and the Roztocze highlands. About $18 \%$ of springs drain water-bearing Quaternary sediments, and for a similar number of springs the kind of a water-bearing layer was not specified. The most numerous are springs with low discharge, for the discharge values of $49 \%$ of groundwater outflows do not exceed $1 \mathrm{~L} / \mathrm{s}$. For $26 \%$ of springs the discharge is in the range of $1-10 \mathrm{~L} / \mathrm{s}$. Only $13 \%$ of springs have discharge rates greater than $10 \mathrm{~L} / \mathrm{s}$. In the year 2000, there were 21 springs with discharge rates of more than $100 \mathrm{~L} / \mathrm{s}$, and other 37 springs had discharge rates in the range of 50-100 L/s. Springs with greatest discharge values usually occur in river valleys, in the proximity of larger side valleys or in zones of tectonic discontinuity of rock layers.

Overall, the average discharge for all springs in the Wyzyna Lubelska highland is about $13 \mathrm{~m}^{3} / \mathrm{s}$. During periods of lowered groundwater table levels, the average discharge value decreases to $6.7 \mathrm{~m}^{3} / \mathrm{s}$, and when the groundwater table levels are high it increases to approximately $18.0 \mathrm{~m}^{3} / \mathrm{s}$. These waters are of highest quality and almost always they satisfy the standards required for drinking water. Nitrate contamination is not a problem in the area at this point.

Spring discharge values do change, and they undergo a multiannual cycle of changes. In addition to that, at the same time, a seasonal pattern of changes exists that is superimposed on the multi-annual cycle. The seasonal changes occur due to an increased recharge in the spring. The age of water in five springs located in the catchment of the Bystrzyca River, determined based on tritium data (Zuber et al., 2001) ranged from 54 to more than 200 years. Coefficients of discharge variability for large springs (greater than $10 \mathrm{~L} / \mathrm{s}$ ) that have been determined based on measurements, performed at different time intervals, are in the range of 1.5-6.0. This allows classification of these springs as belonging to the group of springs having constant or slightly variable discharge.

The largest groundwater outflow in the Wyzyna Lubelska and Roztocze highlands is the spring in Zaporze (57) located in the catchment of the Por River. Its average discharge is $302 \mathrm{~L} / \mathrm{s}$. Average multi-annual discharge rates of the next largest 12 springs are in the range of 100-200 L/s. They are the springs located in the catchment of the Bystrzyca River: Piotrowice (58) and Zakrzowek I (59), the springs in the Gielczwia catchment: Stryjno (60) and Sobieska Wola (61), and the springs in the adjacent Wieprza River basin: Hutki (62) and Stokowa Gora (63). The remaining springs are the springs in the Sanna River catchment: Lute (65) and Wierzchowiska-Stoki (66), the springs in the Biala Lada catchment: Malinie (67) and Abramow (68) as well as the springs: Solokije (69) in the Solokija River basin and Swidry (70) in the Potok Losinecki creek basin. Another typical and well-known groundwater outflow is the spring in Wawolnica (71), listed above in Table 1. An observation data series of unique length has been collected on the discharge of this spring, going back to 1946 . The discharge rate of the spring in the years 1946-2010 changed from 50 to $160 \mathrm{~L} / \mathrm{s}$, with an average of $87 \mathrm{~L} / \mathrm{s}$. Different numbers of measurements were performed in different years. However, Fig. 3 presents a relatively homogeneous data series that represents measurements of discharge for the period of late spring. The discharge rate of the spring shows a multi-annual cyclical pattern of change, clearly related to fluctuations in the underground water reserves in aquifers (Michalczyk and Turczynski, 1999).

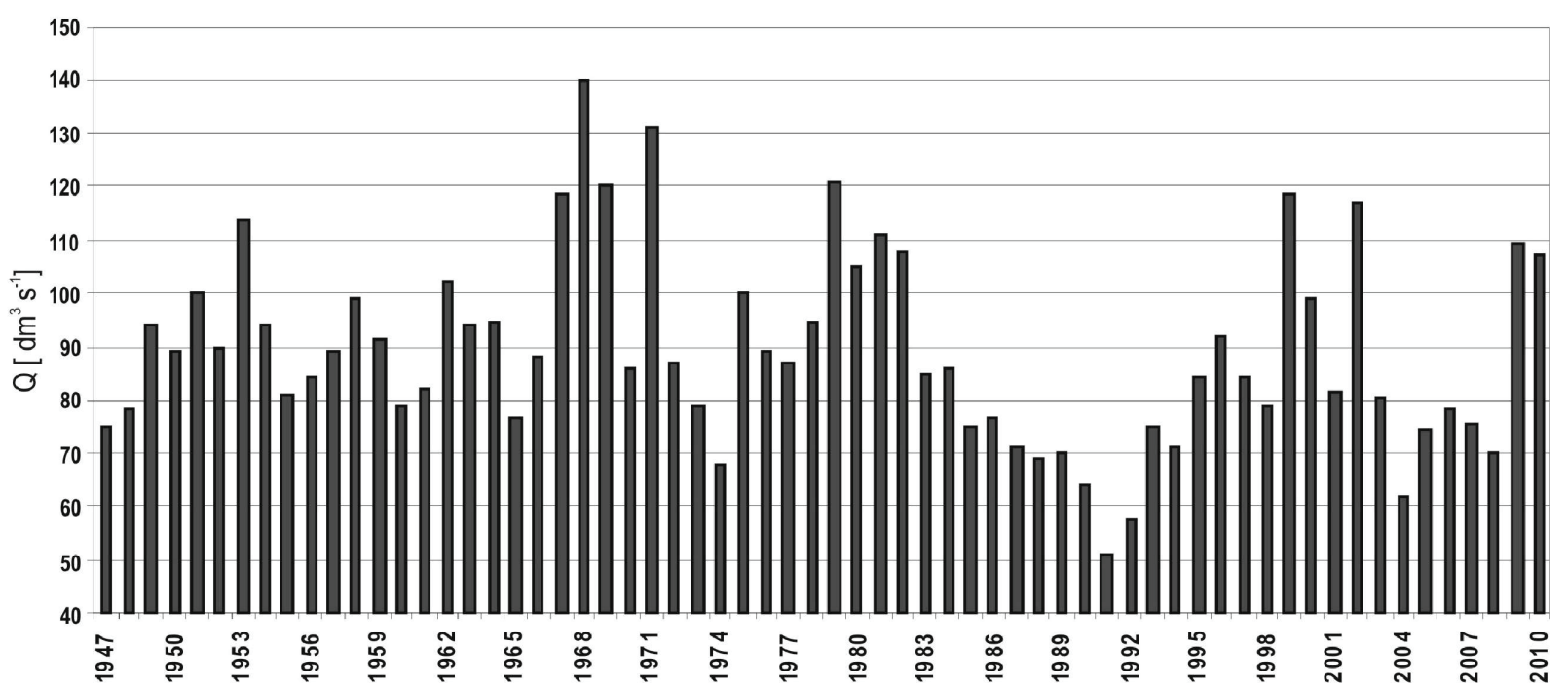

Figure 3. Discharge rate of the spring in Wawolnica (49) in the Wyzyna Lubelska highland in the years 1947-2010 during late spring (June). Also see Table 1. 
A few small springs are also found in the Kotlina Sandomierska and in the Polesie Lubelskie regions. Discharge rates of these springs usually do not exceed $1 \mathrm{~L} / \mathrm{s}$. Only in the Polesie region, some individual springs located near Cretaceous rock outcrops have greater discharge values.

THE POLISH LOWLANDS is a large area that is not uniform when it comes to the distribution of springs and other groundwater outflows, like seeps. Springs are practically absent in flat areas of denudation plains, in swampy terrains, and in river deltas. Most frequently, the presence of springs is associated with cliffs, lake troughs or break-through parts of river valleys. Sometimes groundwater outflows occur at the foot of sandurs or moraine hill chains. In such cases an aquifer is located within sand and glacifluvial gravel formations, or more rarely within dune sands. The groundwater outflows are mostly scattered forms of springs: seeps, hillside dripping springs and bog-springs. Typical single springs are also present, but their discharge rates are usually small. However, there are groups of springs, that even combine different types of springs within a common area, and they may have significant sizes and have quite a large discharge rate.

Younger glacial lowlands, and especially the areas of terminal moraines of a former glacial ice cap possess most favorable morphological and hydrogeological conditions for the formation of spring niches. Groundwater outflows are concentrated primarily in river valleys, in lake troughs, in former ice marginal valleys, and also in glacitectonic deformation zones and in seashore cliffs. The first water table, found in sand and gravel sediments overlying a clayey stratum, usually recharges small descending springs and very low discharge springs, whereas large outflows, including ascending springs, usually flow out of a deeper submorainic level (intermorainic). It is typical for such areas that there is a significant share of scattered groundwater outflows. For example, 187 groundwater outflows have been recorded on the edges of the Wysoczyzna Elblaska upland, out of which $68 \%$ were identified as bog-springs, and only $32 \%$ were typical springs.

Spring density in terminal moraine zones may equal the spring density in highlands. The spring density index for the Pojezierze Suwalskie lake districts is less than 0.3 spring per $\mathrm{km}^{2}$, but in some areas may be several times higher. The groundwater outflows present across the Coastal Lowlands are generally small. Mostly they are very low discharge springs (less than $1 \mathrm{~L} / \mathrm{s}$ ). Low discharge rates of these springs result primarily from substantial differences in the lithology of surface formations and discontinuities in inter-morainic water-bearing layers. Porosity of rocks in a water-bearing layer is also significant as well as is the spring type, which is often a filtration spring that issues from a permeable medium over a relatively large area. The maximum discharge rate occurs in the spring after snowmeltwater infiltrates the ground. The minimum discharge rate occurs in the winter, when the ground is frozen (Jekatierynczuk-Rudczyk, 1999).

Springs with discharge rates greater than $10 \mathrm{~L} / \mathrm{s}$ occur quite frequently in lake districts. There are many examples, such as the group of springs in the Jezioro Kopalinskie Lake basin, with a discharge of $13.8 \mathrm{~L} / \mathrm{s}$ (73), or the group of springs with a discharge of 13.5 L/s in the Bychowska Struga valley (74), just to name a few. An example of a large spring group may be "Staniszewskie Zdroje" (75), with an average combined discharge of $48 \mathrm{~L} / \mathrm{s}$, which is considered to be the largest spring area in northern Poland (Herbich, 1998). The Lyna River springs (76) have also substantial discharge rates. One of the spring groups (77) located on the shore of the Jezioro Zapowiednik Lake, in the Pojezierze Slawskie lake district, has a combined discharge rate of $100 \mathrm{~L} / \mathrm{s}$. Also, one of the spring groups located in the relatively flat Pradolina Torunsko-Eberswaldzka post-glacial valley (a post-glacial river valley that was formed at the terminus of a receding and melting ice cap), has a discharge rate of up to $160 \mathrm{~L} / \mathrm{s}$ (78).

It is typical for large spring groups that are recharged from the submorainic or sandur water-bearing level that their discharge rates are very stable or only slightly variable. The Maillete's variability coefficient for these spring groups is less than 2 , $(\mathrm{M}<2)$. The above mentioned "Staniszewskie Zdroje" (M=1.6) as well as the spring group (79) in the Gryzynka basin ( $M=1.3$ to 1.8$)$ belong to this very collection of springs.

In the post-glacial areas of older glaciations the hydrogeological conditions are less favorable for the development of springs. Small differences in the elevation of terrain and smaller thickness of waterbearing sediment strata in comparison with the post-glacial areas of younger periods of glaciation, mean that springs of any type are less numerous here. Also, their discharge rates are usually small. There are two regions that are different to the rest, where the index of spring density is relatively high and the locations of springs are well known. The spring density index for the Suprasl River catchment is 0.3 spring per $\mathrm{km}^{2}$, and the discharge of large spring groups (80) reaches $97 \mathrm{~L} /$ s. In the city of Bialystok (81) 41 springs have been recorded. Their discharge rates reach $2.5 \mathrm{~L} / \mathrm{s}$.

In central Poland the spring groups with greatest discharge rates are recharged from aquifers of intermorainic water-bearing level associated with sands and glacifluvial gravel formations. Most of the springs are located in river valleys. The spring group in Wierzchowiec (82) has a significant discharge of $17 \mathrm{~L} / \mathrm{s}$, the spring group in Wierzchy Strzyzewskie (83) discharges water at a rate of $23 \mathrm{~L} / \mathrm{s}$, and the spring group in Podwodka (84) discharges water at a rate of $12 \mathrm{~L} / \mathrm{s}$.

The Wzniesienia Lodzkie Hills are a part of the Lowlands. Greater groups of springs occur at the foot of layered formations left by the receding ice cap of the Vistulian glaciation period. They are mostly contact springs, occurring when water is seeping out of a porous rock layer overlaying an impervious layer, descending springs, and springs that issue at the foot of a hill. They are recharged from three basic water-bearing levels. Sands and fluvioglacial gravels create additional water-bearing layers, separated by boulder clay layers. In some places, water within deeper water-bearing levels is pressurized, and so about $10 \%$ of springs, especially those that occur in deep valleys, are ascending springs.

Discharge rates of these springs are generally low $(0.1-1 \mathrm{~L} / \mathrm{s})$. Only $20 \%$ of the springs may be classified as fifth-magnitude springs, and $4 \%$ may be classified as fourth-magnitude springs in Meinzer's units. Nevertheless, when it comes to their discharge variability, they should be classified as stable springs or springs of insignificant variability ( $\left.\mathrm{M}=1.7-2.5 ; \mathrm{C}_{\mathrm{v}}=10.4-21.7 \%\right)$. This fact is owed to large water holding potentials of the aquifers being drained, which on average, range from $11,500 \mathrm{~m}^{3}$ to $227,000 \mathrm{~m}^{3}$. High coefficients of autocorrelation (statistically significant at the level of $\alpha=0.05$, even up to $R_{9}$ ) and a slow rate of water exchange (with a maximum of twice a year, and a minimum of once in 10 years) also attest that the water reserves in the drained aquifers as well as their size are large.

Less than twenty spring groups with discharge rates exceeding 

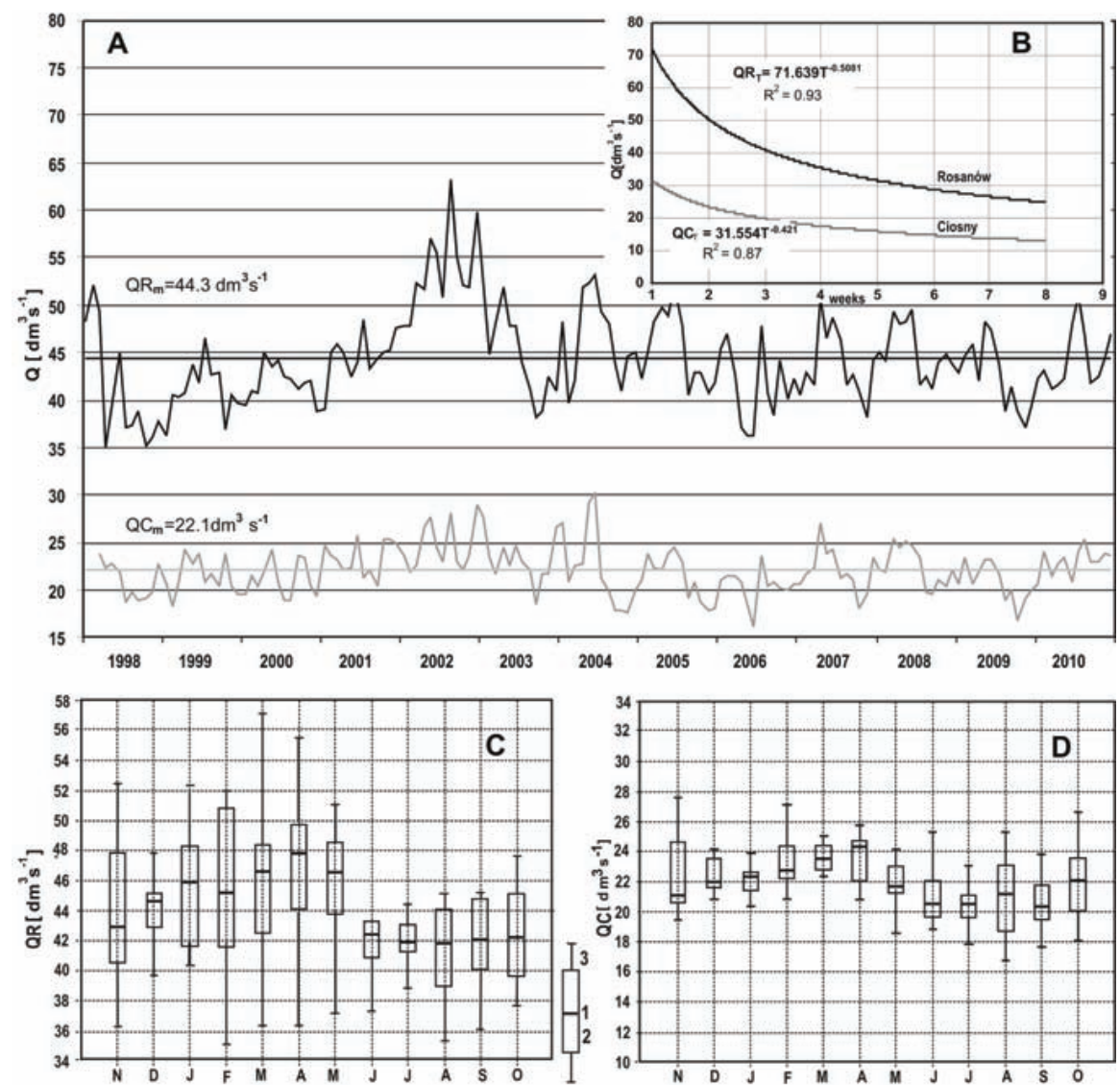

Figure 4. Average monthly and multi-annual discharge values of the Rosanow (QR) and the Ciosny (QC) spring groups in the years 1998-2010 (A). Recession curves for the spring groups are shown (B) as well as seasonal changes in the discharge rates of the Rosanow $(C)$ and the Ciosny spring groups $(D) .1$ - median, 2 - the spread (difference of min and max values) for the $50 \%$ of population interval, 3 - the spread for the interval determined by the criterion of 1.5 of IQR (Inter-quartile Range).

$10 \mathrm{~L} / \mathrm{s}$ have been identified in the Wzniesienia Lodzkie Hills. Some of the springs are: "Ciosny" (85) discharging water at a rate of $22 \mathrm{~L} /$ s, "Borki" (86) with a discharge of $33 \mathrm{~L} / \mathrm{s}$, and "Rosanow I" (87) discharging water at a rate of $44 \mathrm{~L} / \mathrm{s}$. The "Rosanow I" spring group is the largest groundwater outflow discharged from an aquifer composed of Quaternary sediments in central Poland (Moniewski, 2004). Two large spring groups: "Rosanow I" and "Ciosny" were systematically monitored in the years 1998-2010 (Fig. 4). The two spring groups drain the same sandy aquifer located in a postglacial sandur area. However, changes in their discharge rates are not fully synchronized with one another $\left(\mathrm{r}^{2}=0.17\right.$; Fig. $\left.4 \mathrm{~A}\right)$. Also, a multi-annual variability of discharge for the "Rosanow" spring is much greater than the one calculated for the "Ciosny" spring (Fig. 4C,D). A stream runoff produced by the spring groups is slightly higher in the cold half of the year $(51.5 \%)$ than in the warm half of the year $(48.5 \%)$. The discharge rate is highest in April, which is the period of time when the volume of water in the aquifer is at its maximum. A slow pace at which the volume decreases attests that the holding capacity of the aquifer is large. This causes that a stability of discharge may be maintained ( $\mathrm{M}=1.8$ to 1.9 ; Fig. $4 \mathrm{~B}$ ).

Pre-Quaternary bedrock formations (primarily Mesozoic), especially in the valleys of larger rivers that cut into Quaternary sediments, may in the Lowlands also recharge large ascending springs with high discharge rates. Their regime is often similar to the regime of highland springs. The largest and best known are the Blue Springs (Niebieskie Zrodla) (88) in Tomaszow Mazowiecki that are recharged from the limestones covered by alluvial sediments of the Pilica River. At present, their discharge is about $70-80 \mathrm{~L} / \mathrm{s}$ (it used to be over $200 \mathrm{~L} / \mathrm{s}$ ), with the variability index M=2 (Malecka, 1997b). Springs located in the Warta River valley are very much like the Blue Springs. For example, the Navy Blue Springs ("Granatowe Zrodla" (89) located in the Zaleczanski Natural Landscape Park, and the spring in Kochlewo (90) discharging water at a rate of $18 \mathrm{~L} / \mathrm{s}$. Also, the springs of the Nieciecz River (91), discharging water at a rate of $6 \mathrm{~L} / \mathrm{s}$, and of the Widawka River (92), discharging water at a rate of $15 \mathrm{~L} / \mathrm{s}$, flow out of pre-Quaternary formations.

\section{Spring utilization and protection}

In Poland, only $22 \%$ of drinking water and industrial water comes from ground sources. Only a small fraction of the groundwater used comes from springs, which provide only a fraction of the discharge of the largest springs in Dinaric, Slovenian and Alpine karst regions.

One of the best known karst springs in Poland is the Bystra Spring in the Tatra Mountains (3) with a maximum rate of discharge of more than $1 \mathrm{~m}^{3} / \mathrm{s}$. The spring feeds a stream, which has been used as a source of drinking water for the residents of the city of Zakopane for more than one hundred years. The Pinczow Spring in the Niecka Nidzianska Basin has been used as a source of drinking water since 1870. It supplied about $180 \mathrm{~m}^{3} / \mathrm{h}$, however, as demand increased over time, well water became the dominant source $\left(300 \mathrm{~m}^{3} / \mathrm{h}\right)$. The Rosanow I Spring (75) and the Bystrzyca Dusznicka Spring (7) are also used as sources of water. On the other hand, the Bialogon Spring near the city of Kielce (50) dried up due to the construction of numerous wells in the area. The spring was active in the early $20^{\text {th }}$ century, A spring located near Olkusz - a town north of Krakow also lost its ability to supply water.

Several decades ago, many springs across the southern and central highlands of Poland were used by mills. Today most of the mills are no longer in operation. Most of the mills are wooden structures, which have become historical sites since. One example of this is the "Zrodlo spod Mlyna" in Kamienczyce (36), which serves as a natural monument. The same is true of the Rosanow Spring (65).

Small springs were often used by local residents as sources of drinking water. Today water mains supply most of the drinking water in Poland and consequently less than $10 \%$ of springs continue to be used as sources of drinking water. In the Carpathian Mountains, however, some households do obtain spring water from gravitational springs.

Some larger springs supply commercial fish ponds such as Krasnik in the Lublin Upland, Zyrardow near the city of Warsaw, a 
trout fishery operating since 1850 in the Szklarka Valley near the city of Krakow and another trout fishery (1881) in the Wiercica Valley near the city of Czestochowa. Two benefits of using spring water in fish ponds is the resulting temperature stability and the fact that spring water does not carry the eggs of competing fish species.

Some springs supply water to food processing plants. Bottled water sold as spring water is sourced from deep underground aquifers.

While most springs are not commercially used, they nevertheless have not retained their natural physical form. The best natural outflows of groundwater have been given protected status in light of their landscape, research, educational and cultural value (Bascik et al., 2009). In agricultural areas, the main problem is groundwater nitrate contamination. For example, across the highlands of southern Poland north of the city of Krakow, the concentration of $\mathrm{NO}_{3}^{-}$in the mid1990s ranged from 8.0 to $27.0 \mathrm{mg} / \mathrm{L}$ in the Upper Jurassic karstic reservoir, and from 2.6 to $40.3 \mathrm{mg} / \mathrm{L}$ in the Upper Cretaceous reservoir in marls.

Later research (2001-2002) on almost 50 springs documented values ranging from 7.7 to $39.7 \mathrm{mg} / \mathrm{L}$, and from 1.7 to $60.6 \mathrm{mg} / \mathrm{L}$ in the respective reservoirs (Siwek, 2004).

While nitrate contamination normally does not exceed the boundary value of $50 \mathrm{mg} / \mathrm{L}$ (Council Directive 91/676/EEC), values ranging from 20 to $40 \mathrm{mg} / \mathrm{L}$ clearly exceed "natural" concentrations.

In accordance with the Water Framework Directive (2000/60/ EC) and Groundwater Directive (2006/118/EC), the national groundwater monitoring network includes monitoring of the groundwater quantitative status and groundwater quality status. The monitoring is carried out by the Polish Geological Institute, which runs a network of 830 water level monitoring sites and 790 water quality sampling sites. Only 36 of the sites are springs. The water level and water quality data are published quarterly by the Polish Hydrogeological Survey.

\section{Summary}

The state of knowledge of spring hydrology and spring distribution in Poland varies from one region to another. Generally, the discharge rates of most springs are low. In exceptional cases, the discharge of a spring reaches third class in Meinzer's units. In some regions, it is not only the percentage of recorded springs that is insufficient, but foremost the level of knowledge on their discharge regimes and their relationship to the capacities of water-bearing layers being drained. Not much is known on the phenomenon of spring disappearance and migration of springs along valley axes. Opinions on the causes of these phenomena are rather unequivocal: the process of drying-up of springs and of decreasing spring elevation are facts in Poland and that it progresses at an ever faster rate. These issues affect not only urban areas, but also areas of a quasi-natural landscape. However, when one wants to confirm the existence of these issues through an analysis of specific data, another difficulty quickly arises, because the amount of reliable and comparable information on the subject is still very small. In addition to the drying-up of springs, another problem has appeared that is ecologically dangerous, which can be described as reckless spring destruction.

The natural look of most large springs and karst springs in Poland has been substantially changed. This has occurred in spite of the fact that many springs are located in national parks, natural landscape parks, nature reserves, or were declared as natural monuments or ecological land use areas. Research in the field indicates that such forms of protection are insufficient to provide results. All too often spring niches become dumpsites, and the lack of adequate protection zones causes that spring waters become polluted. There are also cases of turning spring niches into "economic development areas" and using the bottoms of valleys with multiple spring outlets to create commercial fishing ponds, recreational use lakes or garden ponds. This causes devastation to the springs existing there and destruction of their biocenoses. What is really important is the introduction of effective measures of protection by law through education and making the public aware of the goals of protecting nature.

Regardless of how one grades the state of knowledge of springs and their distribution in Poland, there is still an insufficient network providing long-term monitoring of springs. Monitoring of springs conducted by academic research groups is usually a short-term and project-based endeavor. It may not become a basis for the evaluation of long-term trends in discharge variability and spring water chemistry. Moreover, there exists a need for a more integrated work effort on the part of researchers from many different research centers, including specialists in various scientific disciplines. That is because springs are an interesting subject for interdisciplinary research (hydrology, hydrogeology, hydrobiology, hydrochemistry). Finally, the ecological state of springs may be a fine indicator to be used in the evaluation of environmental changes.

\section{References}

Absalon D., 2007, Charakterystyka hydrologiczna i termika wybranych zrodel w zlewni Bialki Lelowskiej (Hydrological characteristics, temperature data for selected springs, and spring density in the Bialka Lelowska River basin) in Jokiel, P., Moniewski, P., and Ziulkiewicz, M., eds, Zrodla Polski. Wybrane problemy krenologiczne: Lodz, Wydz. Nauk Geogr. UL, pp. 117-128.

Allen, E.T., 1936, Hot springs of the Yellowstone National Park: Carnegie Inst. Washington, News Serv. Bull., v. 4, no. 1, 525 pp.

Barczyk, G., 2008, Tatrzanskie wywierzyska. Krasowe systemy wywierzyskowe Tatr Polskich (Vauclusian springs of the Tatra Mountains. Karst systems of vauclusian springs in the Polish Tatra Mountains): Zakopane, TPN, 178 pp.

Bascik, M., Chelmicki, W., and Urban J., 2009, Geoconservation of Springs in Poland: Episodes, v. 32, no. 3, pp. 177-185.

Breckenridge, R.M., and Hinckley, B.S., 1978, Thermal springs of Wyoming: Laramie, Wyoming, Wyoming State Geol. Surv. Bull., v. 60, 104 pp.

Brune, G., 1975, Major and historical springs of Texas: Austin, Texas Water Development Board, Report, v. 189, 94 pp.

Chelmicki, W., 1993, The Annual Regime of Shallow Groundwater Levels in Poland: Groundwater, v. 3, pp. 383-388.

Chelmicki, W. (ed.), 2001, Zrodla Wyzyny Krakowsko-Wielunskiej i Miechowskiej. Zmiany w latach 1973-2000 (Springs of the KrakowskoWielunska and Miechowska Uplands. Changes in 1973-2000): Krakow, Inst. Geogr. i Gosp. Przestrz. UJ, 127 pp.

Chowaniec, J., 2009, Studium hydrogeologii zachodniej czesci polskich Karpat (Hydrogeology study of the western part of the Polish Carpathians), Biul. Pol. Geol. Inst., nr. 434, 98 pp.

Collins, W.D., Foster, M.D., Reeves, F., and Meacham R.P., 1930, Springs of Virginia: Charlottesville, VA, Virginia Comm. on Cons. and Development, Water Res. and Power Div., Bull., no. 1, 55 pp.

Czarnecka, H., 1964, Kilka uwag o zrodlach wyzyn poludniowych (A few remarks on springs of the southern highlands): Gosp. Wodna, Biul. PIHM, no. 12 , p. 475 .

Czarnecka, H., 1970, Rozmieszczenie i rezim hydrologiczny zrodel na Wyzynie Malopolskiej (Spatial distribution and hydrological regime of 
springs in the Wyzyna Malopolska highland): Prace PIHM, no. 100, pp.71-78.

Czarnecka, H., 1973, Rozmieszczenie zrodel na Wyzynie Malopolskiej (Spatial distribution of springs in the Wyzyna Malopolska highland): Prace i Studnia IG UW, no. 24: pp. 5-70.

Czarnecka, H., 1975, Rezim zrodel na Wyzynie Malopolskiej (Hydrological regime of springs in the Wyzyna Malopolska highland): Prace IMGW, no. $6,151 \mathrm{pp}$.

Drzal, M., and Dynowska, I., 1981, Cenne przyrodniczo zrodla na Wyzynie Krakowsko-Wielunskiej (Valuable natural springs in the Wyzyna Krakowsko-Wielunska highland): Studia Osr. Dok. Fizjogr., no. 8, pp. 327-381.

Dynowska, I., 1983, Zrodla Wyzyny Krakowsko-Wielunskiej i Miechowskiej (Springs of the Wyzyna Krakowsko-Wielunska and Miechowska highlands): Studia Osr. Dok. Fizjogr., no. 9, 244 pp.

Dynowska, I., 1986, Regionalne zroznicowanie zrodel w Polsce (Regional diversity of springs in Poland): Folia Geogr., ser. Geogr.-Phys., no. 18, pp. 5-30.

Dynowska, I., 1994, Zrodla (Springs) in: Atlas zasobow, walorow i zagrozen srodowiska geograficznego Polski (Atlas of resources, natural wealth and attractions, and threats to the geographical environment of Poland): Warszawa, IGiPZ PAN, plate 16.

Flippo, H.N. Jr, 1974, Springs of Pennsylvania: US Geological Survey, Water Res. Bull., no. 10, 46 pp.

Gradzinski, M., Hercman, H., Kicinska, D., Barczyk, G., Bella, P., and Holubek P., 2009, Kras tatrzanski - rozwoj wiedzy w ostatnich trzydziestu latach (Karst areas of the Tatra Mountains - a development of knowledge over the last thirty years): Przegl. Geol., v. 57, no. 8, pp. 674-684.

Hartnett, F.M. (ed.), 2000, Florida's springs: strategies for protection and restoration: Tallahassee, FL, Florida Dept. of Env. Protection, 59 pp.

Herbich, J., 1998, Staniszewskie Zdroje - ochrona szaty roslinnej zrodlisk (Staniszewskie Zdroje - protection of flora in spring group areas), in Herbich, J., and Herbichowa, M. eds, Szata roslinna Pomorza zroznicowanie, zagrozenia, ochrona, Przewodnik Sesji Terenowej 51 Zjazdu PTB, Wyd. UG, Gdansk, pp. 181-186.

Humnicki, W., 2006, Rezim zrodel pieninskich w swietle obserwacji limnimetrycznych (Hydrological regime of the Pieniny Mountains' springs in light of water level observations) in Pieniny - Przyroda i Czlowiek, no. 9, pp. 29-39.

Humnicki, W., 2007, Hydrogeologia Pienin (Hydrogeology of the Pieniny Mts.): Warszawa, Wyd. UW, 240 pp.

Janiec, B., 1972, Zrodla poludniowej krawedzi Wyzyny Lubelskiej i ich zwiazek z tektonika (Springs of the southern edge of the Wyzyna Lubelska highland and how the presence of springs is related to tectonics): Biul Lub. Tow. Nauk., ser. D, v. 14, 63-67 pp.

Jekatierynczuk-Rudczyk, E., 1999, Effects of drainage basin management on the chemical composition of waters in lowland springs: Acta Hydrobiol., v. 41, pp. 97-105.

Jokiel, P., 1994, Wieloletnie i sezonowe zmiany wydajnosci wybranych zrodel Polski (Multi-annual and seasonal changes in the discharge rate of selected springs in Poland): Wiad. IMGW, v. 18(38), no. 4, pp. 117-130.

Jokiel, P., 1996, Wzorcowe krzywe wysychania i potencjaly zasobnosci kilkunastu zrodel karpackich (Spring recession curves and associated potential water resources of some Carpathian springs): Wiad. IMGW, vol. 19(40), no. 2, pp. 67-77.

Jokiel, P., 1997, Podstawowe cechy rezimu wydajnosci wybranych zrodel karpackich (Basic characteristics of the discharge regime of selected Carpathian springs): Acta Univ. Lodz., Folia Geogr. Phys., no. 2, pp. 2743.

Kleczkowski, A.S., 1971, Wydajnosæ minimalna glownego zrodla Pradnika i znaczenie ochrony jego wod dla Ojcowskiego Parku Narodowego (Minimum discharge of the main spring of the Pradnik River and the significance of the protection of its water to Ojcowski National Park): Ochr. Przyr., no. 36, pp. 361-378.

Klimaszewski, M., 1956, The Detailed Hydrographical Map of Poland: Przegl. Geogr., no. 28, suppl., pp. 41-47.
Kostrakiewicz, L., 1996, Regionalizacja wskaznika krenologicznego w polskich Karpatach Wewnetrznych (Regional nature of the spring density index in the Polish Carpathians): Wszechswiat, v. 97, no. 3, pp. 61-66.

Kresic, N., Stevanovic Z., (ed), 2010, Groundwater Hydrology of Springs. Engineering, Theory, Management, and Sustainability, Elsevier, 574 pp.

Lajczak, A., 2001, Zrodla mineralne Niecki Nidzianskiej (Mineral springs of the Nidzianska Basin): Czasop. Geogr., v. 72, no. 2, pp. 151-184.

Macioszczyk, T., 1959, Niektore problemy hydrogeologii zrodel zachodniego Podhala (Selected hydrogeology issues of the western Podhale springs): Przegl. Geol., no. 8, pp. 372-375.

Malecka, D., 1997a, Zrodla masywu tatrzanskiego (Springs of the Tatra Mts. massif): Acta Univ. Lodz., Folia Geogr. Phys., no. 2, pp. 9-26.

Malecka D., 1997b, Zmiany wydajnosci Niebieskich Zrodel. Przyczyny i skutki (Changes in the discharge of the Niebieskie Zrodla (Blue Springs). Causes and effects): Acta Univ. Lodz., Folia Geogr. Phys., no. 2: pp. 95114

McColloch, J.S., 1986, Springs of West Virginia: Morgantown, West Virginia Geological and Economic Survey. Mont Chateau Research Center, 493 pp.

Michalczyk, Z., 1986, Warunki wystepowania i krazenia wod na obszarze Wyzyny Lubelskiej i Roztocza (The conditions for the occurrence of water and water circulation in the Wyzyna Lubelska and Roztocze highlands): Lublin, Wyd. UMCS, 199 pp.

Michalczyk, Z., (ed), 2001, Zrodla Wyzyny Lubelskiej i Roztocza (Springs of the Wyzyna Lubelska highland and the Roztocze region): Lublin, Wyd. UMCS, 298 pp.

Michalczyk, Z., and Turczynski, M., 1999, Charakterystyka hydrologiczna zrodel w Wawolnicy na Wyzynie Lubelskiej (Hydrological characteristics of the springs in Wawolnica in the Wyzyna Lubelska highland), Annales UMCS, sec.B., v. 54, pp. 217-234.

Moniewski, P., 2004, Zrodla okolic Lodzi (Springs of the Lodz region): Acta Geogr. Lodz., no. 87.

Mundorff, J.C., 1979, Major thermal springs of Utah: Utah Geol. and Mineral. Surv., Water-Res. Bull. no. 13, 60 pp.

Pacheco, F.A.L., Alencoão, A.M.P., 2002, Occurrence of springs in massifs of crystalline rocks, northern Portugal: Hydrogeol. J., vol. 10 (2), pp.239253.

Paczynski, B., 1995, Atlas hydrogeologiczny Polski (Hydrogeologiczal Atlas of Poland 1:500 000, Wyd. PAE, Warszawa.

Paczynski, B. \& Sadurski, A. (eds.), 2007, Hydrogeologia regionalna Polski, tom I (Regional Hydrogeology of Poland, v. 1, Panstw. Inst. Geol., Warszawa: $542 \mathrm{pp}$.

Pawlik-Dobrowolski, J., 1965, Uzrodlowienie Poludniowej Polski (Spring density index in South Poland): Zesz. Nauk. UJ, vol. 117, Prace Geogr., no. 12 , pp. 7-42.

Pérez, E.S., 1996, Springs in Spain. Classification According to Their Flows and Lithologies and Their Hydraulic Contributions: Ground Water, v. 34, no. 6, pp. 1033-1041.

Rederowa, E., 1965. Zrodla Bystrzycy Lubelskiej (Springs of the Bystrzyca Lubelska river): Annales UMCS, sec. B, no. 18, pp. 229-244.

Rederowa, E., 1971, Wystepowanie zrodel na Wyzynie Lubelskiej i w obszarach przyleglych. (The occurrence of springs on Lublin Upland and in nearby areas): Przegl. Geogr., v. 43, no. 3, pp. 355-360.

Rozkowski, J, 1998, Endangering of the Upper Jurassic karst-fissured aquifer in the Krakow Upland (southern Poland): Env. Geol., v. 33, no. 4, pp. 274-278.

Rozkowski, J., 2006, Wody podziemne utworow weglanowych poludniowej czesci Jury Krakowsko-Czestochowskiej i problemy ich ochrony (Ground waters in carbonate formations of the southern part of the Jura KrakowskoCzestochowska highland and problems related to their protection): Katowice, Wyd. Uniw. Slaskiego, 264 pp.

Scarsbrook, M., Barquin, J., and Gray, D., 2007, New Zealand coldwater springs and their biodiversity: Science for conservation, v. 278, $72 \mathrm{pp}$.

Siwek, J., 2004, Zrodla w zlewniach Pradnika, Dlubni i Szreniawy. Naturalne i antropogeniczne uwarunkowania jakosci wod (Natural conditions and 
anthropogenic factors that determine water quality): Krakow, Inst. Geogr. i Gosp. Przestrz. UJ, 98 pp.

Stevanovic, Z., Eftimi, R., 2010, Karstic sources of water supply for large consumers in Southeastern Europe - sustainability, disputes and advantages, Geologia Croatica, v. 63, no. 2, pp. 179-185.

Suligowski, R., Kupczyk, E., Kasprzyk, A., and Koslacz R., 2009, Woda w srodowisku przyrodniczym i jej zagospodarowanie w wojewodztwie swietokrzyskim (Water in the natural environment and economic use of water resources in the Swietokrzyskie province): Kielce, Inst. Geogr. UJK, $131 \mathrm{pp}$.

Tlalka, A., and Waksmundzki, K, 1968, Wyniki badan zrodel w Polsce Poludniowej (Results of spring research in South Poland): Przegl. Geogr., v. 40 , no. 2 , pp. $519-524$

Tomaszewski, J.T., 1974, Problematyka wodna mlak i torfowisk Karkonoszy (Bog-springs and peat bogs of the Karkonosze Mountains): Opera Corcontica, no. 11, pp. 37-51.

Vineyard, J.D., and Feder, G.L., 1982, Springs of Missouri: Missouri Dept of Nat. Res., Water Res. Rep., no. 29, 212 pp.

Waring, G.A., 1915, Springs of California: U.S. Geological Survey Water Supply Paper, no. 38, 410 pp.

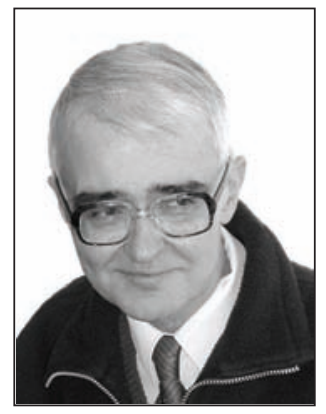

Wojciech Chelmicki - Professor of Physical Geography, Head of the Department of Hydrology, Institute of Geography and Spatial Management, Jagiellonian University in Krakow, Poland. His interests cover groundwater - surface water interactions, human impact on water circulation, water chemistry dynamics and hydrological cartography. He is the national correspondent for Poland in the European Network of Experimental and Representative Basins (ERB).

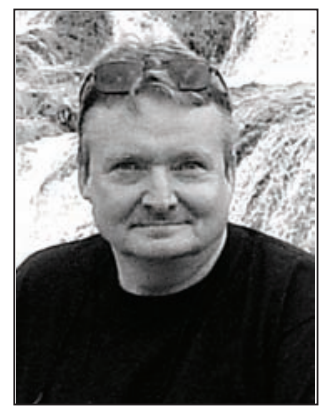

Pawel Jokiel - Professor of Earth Sciences, Head of the Department of Hydrology and Water Management, Institute of Earth Sciences, Univeristy of Lodz, Poland. His interests cover forms and dynamics of river flow, water resources in Poland (river regimes, water balance methodology, springs), human impact onto river flow and groundwater resources (sub-urban areas, highway drainage, open pit mines) and hydrological extremes.
Waring G.A, 1965, Thermal Springs of the United States and Other Countries of the World: Geol. Surv. Prof. Paper, no. 492, 383 pp.

Wit-Jozwik, K, 1974, Hydrografia Tatr Wysokich. Objasnienia do mapy hydrograficznej "Tatry Wysokie" 1:50 000 (Hydrography of the High Tatras. The legend for the hydrographic map of the High Tatras at the scale of 1:50 000): Dokumentacja Geogr., 5, 103 pp.

Wit, K., and Ziemonska, Z., 1960, Hydrografia Tatr Zachodnich. Objasnienia do mapy hydrograficznej "Tatry Zachodnie" 1:50 000 (Hydrography of the West Tatras. The legend for the hydrographic map of the West Tatras at the scale of 1:50 000: Warszawa, Inst. Geogr. PAN, 103 pp.

Zuber, A., Malecki, J.J., and Dulinski, M., 2008, Ground water ages and altitudes of recharge areas in the Polish Tatra Mts. as determined from ${ }^{3} \mathrm{H}, \delta^{18} \mathrm{O}$ and $\delta^{2} \mathrm{H}$ data: Geol. Quarterly, v. 52, no. 1, pp. 71-80.

Zuber, A., Michalczyk, Z., and Maloszewski, P., 2001, Great tritium ages explain the occurrence of good-quality groundwater in a phreatic aquifer of an urban area, Lublin, Poland: Hydrogeol. J., v. 9, pp. 451-460.

Zurek, A., Czop, M., and Motyka J., 2010, Azotany w wodach jurajskiego pietra wodonosnego w rejonie Olkusza (Nitrate in groundwater of the Jurassic aquifer in Olkusz region, southern Poland): Geologia, v. 36, no. 1, pp. 109-134.

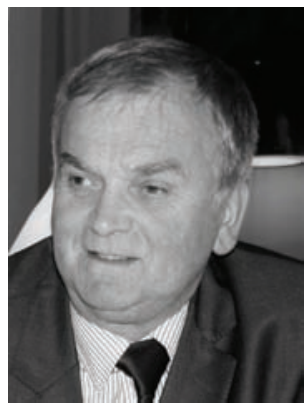

Zdzislaw Michalczyk - Professor of Earth Sciences, Hydrology. Head of the Department of Hydrology, Institute of the Earth Sciences, Maria Curie-Sklodowska University in Lublin, Poland. His main research interests focus on influence of environmental and climatic factors onto water circulation, occurrence, yield, and regime of springs, hydrological consequences of groundwater overexploitation in the city of Lublin, and conditions for groundwater replenishment in urbanized areas.

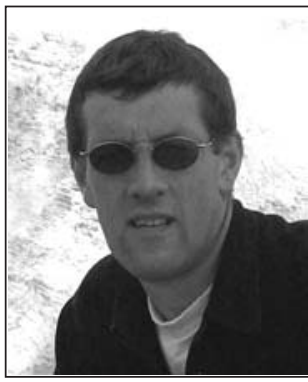

Piotr Moniewski - Researcher at the Department of Hydrology and Water Management, Institute of Earth Sciences, University of Lodz, Poland. His interests focus on groundwater outflows, water resources and hydrological measurement techniques, and human impact on water quality in rural and urbanized drainage basins. 